\title{
Molybdenum(VI) Complexes with Schiff Base Containing N-Hetero Atom
}

\author{
Devendra Pratap Rao ${ }^{1, *}$ (D), Hardeo Singh Yadav 2 ${ }^{\mathbb{D}}$, Chandra Prakash Singh ${ }^{3}$ (D) \\ 1 Department of Chemistry, D.A-V. P.G. College, Kanpur-208001, U.P., India \\ 2 Department of Chemistry, North Eastern Regional Institute of Science and Technology (NERIST), Nirjuli, Arunachal \\ Pradesh, India \\ 3 Department of Chemistry, D.B.S. College, Kanpur - 208006, U.P., India \\ * Correspondence: devendraprataprao@yahoo.com;
}

Scopus Author ID 35119371500

Received: 30.08.2020; Revised: 26.09.2020; Accepted: 27.09.2020; Published: 2.10.2020

\begin{abstract}
Parent dioxomolybdenum(VI) complex formation by the reaction of $\mathrm{MoO}_{2}(\mathrm{acac})_{2}$ with Schiff base tetradentate ligand, described in this paper. Schiff base tetradentate ligand $\left[\mathrm{H}_{2} \mathrm{NCH}_{2} \mathrm{CH}_{2}\right.$ $\left.\mathrm{N}=\mathrm{CC}_{4} \mathrm{H}_{3} \mathrm{~S}-\mathrm{CC}_{4} \mathrm{H}_{3} \mathrm{~S}=\mathrm{NCH}_{2} \mathrm{CH}_{2} \mathrm{NH}_{2}\right]$ obtained from the condensation of di-2-thienylethanedione with 1,2-diaminoethane. Macrocyclic molybdenum complexes were obtained from the cyclization of a synthesized complex with different 1,3 - diketones. The general formula of parent molybdenum complex is given as $\left[\mathrm{MoO}_{2}\left(\mathrm{H}_{2} \mathrm{NCH}_{2} \mathrm{CH}_{2} \mathrm{~N}=\mathrm{CC}_{4} \mathrm{H}_{3} \mathrm{~S}-\mathrm{CC}_{4} \mathrm{H}_{3} \mathrm{~S}=\mathrm{N} \mathrm{CH} \mathrm{CH}_{2} \mathrm{CH}_{2} \mathrm{NH}_{2}\right)\right](\mathrm{acac})_{2}$ and for macrocyclic molybdenum complex is $\left[\mathrm{MoO}_{2}\left\{\left(\mathrm{CH}_{2} \mathrm{CH}_{2} \quad \mathrm{~N}=\mathrm{CC}_{4} \mathrm{H}_{3} \mathrm{~S}-\mathrm{CC}_{4} \mathrm{H}_{3} \mathrm{~S}=\mathrm{N} \quad \mathrm{CH}_{2} \mathrm{CH}_{2}\right)\right.\right.$ $\left.\left.\mathrm{N}=\mathrm{C}(\mathrm{R}) \mathrm{CH}_{2} \mathrm{C}\left(\mathrm{R}^{\prime}\right)=\mathrm{N}\right\}\right](\mathrm{acac})_{2}$. Ligand and all molybdenum complexes were characterized by elemental analyses(EA), molar conductivity $\left(\Lambda_{\mathrm{M}}\right)$, ultraviolet(UV-Vis), and infrared (IR) spectral studies. The distorted octahedral geometry of element Mo in the parent as well as in macrocyclic molybdenum complexes is completed by two oxo $\mathrm{O}$-atoms, four $\mathrm{N}$-atoms from derived Schiff ligand.
\end{abstract}

Keywords: molybdenum complexes;di-2-thienylethanedione; macrocyclic ligand; cyclization.

(C) 2020 by the authors. This article is an open-access article distributed under the terms and conditions of the Creative Commons Attribution (CC BY) license (https://creativecommons.org/licenses/by/4.0/).

\section{Introduction}

Molybdenum is a valuable metal, with its ability to form complexes with several Schiff bases [1-5]. It is a necessary unit of defined enzymes, which catalyze the reduction of molecular nitrogen into ammonia (nitrogen fixation) in plants. It is also a significant unit of that enzymes which catalyze oxidation from aldehyde to carboxylic acid, sulfite to sulfate, olefin epoxidation as well as xanthene to uric acid in animals [6-9]. Oxo- and dioxomolybdenum was studied widely as catalysts for a number of transformation reactions, generally for sulfoxidation [5], O- atom transfer reactions (OAT) [10-18], antioxidant activity [19], and neutral esterification agents [20] as well. Some transition metal complexes with a large selection of oximes and Schiff base and coordination sphere have facilitated us to carry out our work in this area $[21,22]$. Schiff base transition complexes have demonstrated important implications in many transformations as homogeneous as well as heterogeneous catalysts [23], for example, ketones reduction in alcohol medium [24] and alkylation of allylic compounds [25-27]. Metal chelates of oxime present relatively markedly higher biological properties that relative free ligands [28]. Different complexes of oximes showed cytotoxicity in murine and human tissue cultured cells [29]. The purpose of the current research was to prepare a unique molybdenum complex with Schiff base macrocyclic ligands synthesized from the reaction of di-2-thienylethanedione with 
1,2-diaminoethane. This complex was suitable for undergoing cyclization with 1,3-diketones through the metal template effect.

The authors reported the synthesis and formal structures of these parents and cyclized molybdenum complexes based on different characterization viz. molar conductance, EA, infrared, and electronic spectra.

\section{Materials and Methods}

\subsection{Materials.}

All chemicals used for the synthesis of Schiff base, parent, and macrocyclic complexes were of reagent grade. Molybdenyl acetylacetonate, 1,2-diaminoethane, di-2thienylethanedione, and 1,3 - diketones, namely dibenzoylmethane acetylacetone, thenoyltrifluoroacetone, and benzoylacetone were purchased from Aldrich. These were used as such i.e., without further purification.

\subsection{Analytical Methods.}

Elemental microanalysis of the ligand and complexes were carried out at CRF, NERIST, Nirjuli-791109, Itanagar, Arunachal Pradesh, India. The standard method (Kjeldahl) was availed for nitrogen estimation. Metal and sulfur were estimated after the decomposition of the complex by standard methods [30,31]. Undisciplined melting points were evaluated by the standard method using a sulphuric acid bath. The electronic spectra measurements of the ligand and complexes were recorded on c $\Phi 10$ Russian spectrophotometer and Beckmann DU2 spectrophotometer, the ranges $700-400 \mathrm{~nm}$ and $2000-185 \mathrm{~nm}$, and by using methanol as solvent. The infrared spectra $\left(4000-50 \mathrm{~cm}^{-1}\right)$ of the complexes were observed $\mathrm{KBr}$. The models of IR spectrophotometers were Perkin-Elmer 621 and Beckmann Acculab-9.

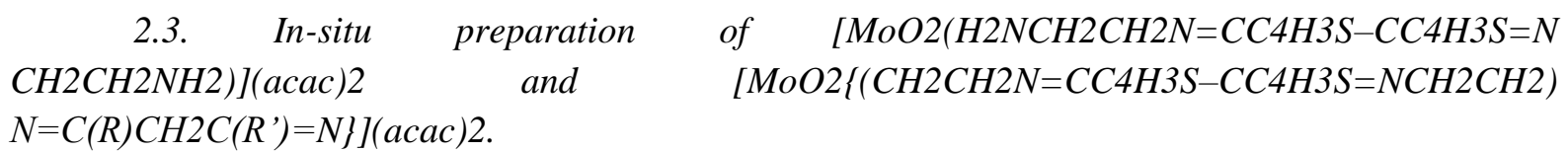

Firstly, refluxed the solution of di-2-thienylethanedione $(2.5 \mathrm{mmol}, 0.5570 \mathrm{~g})$ and 1,2diaminoethane $(5 \mathrm{mmol})$ in $50 \mathrm{~mL}$ ethanol in an RB flask. For the preparation of $\left[\mathrm{MoO}_{2}(\mathrm{mac})\right](\mathrm{acac})_{2}$, the ethanolic solution of molybdenyl acetylacetonate $(2.5 \mathrm{mmol}, 0.8154$ g) was added slowly to the above-refluxed solution. The obtained solution was mildly refluxed for $3 \mathrm{~h}$ and got a dirty yellow color reaction mixture. The precipitate was collected by filtration, washed with cold ethanol, and dried in a vacuum desiccator over silica gel to obtain a solid product. TLC technique was used for checking the purity of the prepared complex (yield: $65 \%$, type ' $\mid \mathrm{A}$ '). Ethanolic mixture of type 'A' complex again reacted for $2 \mathrm{~h}$ with 1,3 -diketones like 2,4-pentanedione or 1-phenyl-1,3-butanedione or 4,4,4-trifluoro-1-(2-thienyl)-1,3-butanedione or 1,3-diphenyl-1,3-propanedione (1:1) to get macrocyclic complex (type 'B'). The purity of the prepared complex was checked by TLC (yield $50 \%$ ) (scheme 1,2 \& 3). The above method was also used to synthesize rest complexes.

The in-situ syntheses of $\left[\mathrm{MoO}_{2}\left(\mathrm{H}_{2} \mathrm{NCH}_{2} \mathrm{CH}_{2} \mathrm{~N}=\mathrm{CC}_{4} \mathrm{H}_{3} \mathrm{~S}-\right.\right.$ $\left.\left.\mathrm{CC}_{4} \mathrm{H}_{3} \mathrm{~S}=\mathrm{NCH}_{2} \mathrm{CH}_{2} \mathrm{NH}_{2}\right)\right](\text { acac })_{2} \quad$ and $\quad\left[\mathrm{MoO}_{2}\left\{\left(\mathrm{CH}_{2} \mathrm{CH}_{2} \mathrm{~N}=\mathrm{CC}_{4} \mathrm{H}_{3} \mathrm{~S}-\right.\right.\right.$ $\left.\left.\left.\mathrm{CC}_{4} \mathrm{H}_{3} \mathrm{~S}=\mathrm{NCH}_{2} \mathrm{CH}_{2}\right) \mathrm{N}=\mathrm{C}(\mathrm{R}) \mathrm{CH}_{2} \mathrm{C}\left(\mathrm{R}^{\prime}\right)=\mathrm{N}\right\}\right](\text { acac })_{2}$ are shown in the following schemes. 


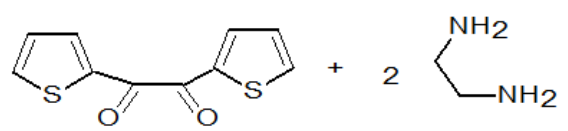

Thenil 1,2 - Diaminoethane

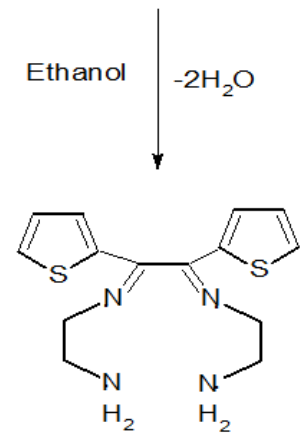

[L]

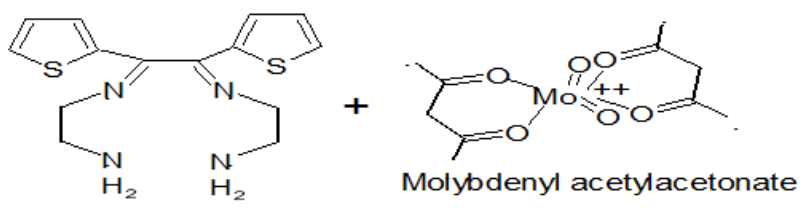

[L]
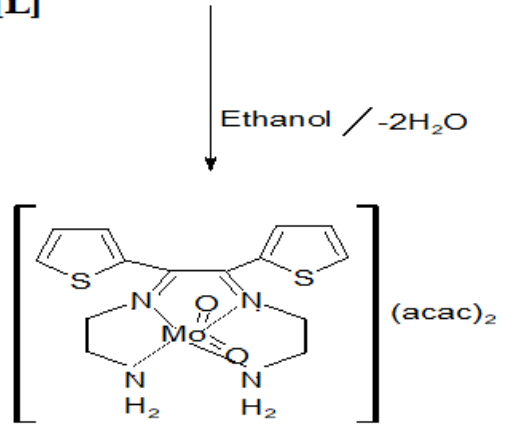

$\left[\mathrm{MoO}_{2}(\mathrm{~L})\right](\text { acac })_{2}$

Type A

Scheme 2. Synthesis of $\left.\left[\mathrm{MoO}_{2}\right)(\mathrm{L})\right](\mathrm{acac})_{2}$

Scheme 1. Synthesis of Ligand (L).

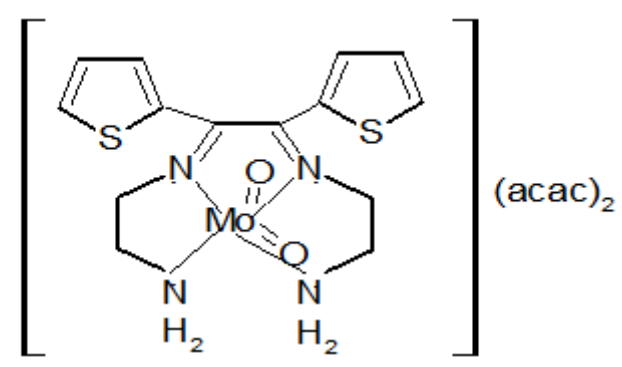

$\left[\mathrm{MoO}_{2}(\mathrm{~L})\right](\text { acac })_{2}$

Type A<smiles>[R]C(=O)CC([R])=O</smiles><smiles></smiles>

$\left[\mathrm{MoO}_{2}(\mathrm{ML})\right](\text { acac })_{2}$

Type B

Where, Ligand (L) obtained from the reaction of Thenil and 1,2-diaminoethane; Macrocyclic ligands (ML) obtained from the reaction of L with 1,3-diketones in presence of $\mathrm{MoO}_{2}$ (VI) cation.

Scheme 3. Synthesis of $\left.\left[\mathrm{MoO}_{2}\right)(\mathrm{M})\right](\mathrm{acac})_{2}$.

The metal to ligand stoichiometry (1:1 molar ratio) was proved by the elemental analyses (table 1) of the complexes. 
Table 1. Elemental analysis of the synthesized complexes.

\begin{tabular}{|c|c|c|c|c|c|c|c|c|c|}
\hline Complex & $\begin{array}{c}\text { Formula } \\
\text { Weight }\end{array}$ & $\begin{array}{c}\text { Empirical } \\
\text { Formula }\end{array}$ & $\begin{array}{c}\text { Mo \% } \\
\text { (Calcd.) } \\
\text { found }\end{array}$ & $\begin{array}{c}\text { C \% } \\
\text { (Calcd.) } \\
\text { found }\end{array}$ & $\begin{array}{c}\text { S \% } \\
\text { (Calcd.) } \\
\text { found }\end{array}$ & $\begin{array}{c}\text { H \% } \\
\text { (Calcd.) } \\
\text { found }\end{array}$ & $\begin{array}{c}\text { N \% } \\
\text { (Calcd.) } \\
\text { found }\end{array}$ & $\begin{array}{c}\text { Decomp. } \\
\text { temp. } \\
\left({ }^{0} \mathrm{C}\right)\end{array}$ & $\begin{array}{l}\text { Yield } \\
(\%)\end{array}$ \\
\hline $\begin{array}{l}\text { Macrocyclic } \\
\text { complex [A] }\end{array}$ & 696.70 & $\begin{array}{c}\mathrm{C}_{29} \mathrm{H}_{36} \mathrm{~N}_{4} \\
\mathrm{~S}_{2} \mathrm{O}_{6} \mathrm{Mo}\end{array}$ & $\begin{array}{c}(13.80) \\
13.70\end{array}$ & $\begin{array}{l}(50.00) \\
49.90\end{array}$ & $\begin{array}{l}(9.20) \\
9.10\end{array}$ & $\begin{array}{c}(5.20) \\
5.10\end{array}$ & $\begin{array}{c}(8.00) \\
7.90\end{array}$ & 304 & 65 \\
\hline $\begin{array}{l}\text { Macrocyclic } \\
\text { complex [B] }\end{array}$ & 758.77 & $\begin{array}{c}\mathrm{C}_{34} \mathrm{H}_{38} \mathrm{~N}_{4} \\
\mathrm{~S}_{2} \mathrm{O}_{6} \mathrm{Mo}\end{array}$ & $\begin{array}{c}(12.60) \\
12.30\end{array}$ & $\begin{array}{c}(53.80) \\
53.60\end{array}$ & $\begin{array}{c}(8.50) \\
8.30\end{array}$ & $\begin{array}{c}(5.04) \\
5.00\end{array}$ & $\begin{array}{c}(7.40) \\
7.30\end{array}$ & 306 & 60 \\
\hline $\begin{array}{l}\text { Macrocyclic } \\
\text { complex [C] }\end{array}$ & 818.77 & $\begin{array}{l}\mathrm{C}_{32} \mathrm{H}_{33} \mathrm{~N}_{4} \\
\mathrm{~S}_{3} \mathrm{O}_{6} \mathrm{~F}_{3} \mathrm{Mo}\end{array}$ & $\begin{array}{c}(11.70) \\
11.60\end{array}$ & $\begin{array}{l}(47.00) \\
46.90\end{array}$ & $\begin{array}{c}(7.00) \\
6.90\end{array}$ & $\begin{array}{l}(4.10) \\
4.00\end{array}$ & $\begin{array}{c}(6.80) \\
6.60\end{array}$ & 305 & 55 \\
\hline $\begin{array}{l}\text { Macrocyclic } \\
\text { complex [D] }\end{array}$ & 820.84 & $\begin{array}{c}\mathrm{C}_{39} \mathrm{H}_{40} \mathrm{~N}_{4} \\
\mathrm{~S}_{2} \mathrm{O}_{6} \mathrm{Mo}\end{array}$ & $\begin{array}{c}(11.70) \\
11.60\end{array}$ & $\begin{array}{c}(57.10) \\
57.00\end{array}$ & $\begin{array}{c}(7.80) \\
7.70\end{array}$ & $\begin{array}{l}(5.00) \\
4.90\end{array}$ & $\begin{array}{c}6.80) \\
6.60\end{array}$ & 304 & 50 \\
\hline $\begin{array}{l}\text { Parent } \\
\text { complex }\end{array}$ & 632.61 & $\begin{array}{c}\mathrm{C}_{24} \mathrm{H}_{32} \mathrm{~N}_{4} \\
\mathrm{~S}_{2} \mathrm{O}_{6} \mathrm{Mo}\end{array}$ & $\begin{array}{c}(15.20) \\
15.20\end{array}$ & $\begin{array}{c}(45.60) \\
45.50\end{array}$ & $\begin{array}{c}(10.10) \\
10.00\end{array}$ & $\begin{array}{c}(5.10) \\
5.00\end{array}$ & $\begin{array}{l}(8.90) \\
8.80\end{array}$ & 305 & 50 \\
\hline
\end{tabular}

Parent complex:

Macrocyclic complex:

$\left[\mathrm{MoO}_{2}\left(\mathrm{H}_{2} \mathrm{NCH}_{2} \mathrm{CH}_{2} \mathrm{~N}=\mathrm{CC}_{4} \mathrm{H}_{3} \mathrm{~S}-\mathrm{CC}_{4} \mathrm{H}_{3} \mathrm{~S}=\mathrm{N} \mathrm{CH}_{2} \mathrm{CH}_{2} \mathrm{NH}_{2}\right)\right](\text { acac })_{2}$

$$
\begin{aligned}
& {[\mathrm{A}] \rightarrow\left[\mathrm{MoO}_{2}\left\{\left(\mathrm{CH}_{2} \mathrm{CH}_{2} \mathrm{~N}=\mathrm{CC}_{4} \mathrm{H}_{3} \mathrm{~S}-\mathrm{CC}_{4} \mathrm{H}_{3} \mathrm{~S}=\mathrm{NCH}_{2} \mathrm{CH}_{2}\right) \mathrm{N}=\mathrm{C}\left(\mathrm{CH}_{3}\right) \mathrm{CH}_{2} \mathrm{C}\left(\mathrm{CH}_{3}\right)=\mathrm{N}\right\}\right](\mathrm{acac})_{2}} \\
& {[\mathrm{~B}] \rightarrow\left[\mathrm{MoO}_{2}\left\{\left(\mathrm{CH}_{2} \mathrm{CH}_{2} \mathrm{~N}=\mathrm{CC}_{4} \mathrm{H}_{3} \mathrm{~S}-\mathrm{CC}_{4} \mathrm{H}_{3} \mathrm{~S}=\mathrm{NCH}_{2} \mathrm{CH}_{2}\right) \mathrm{N}=\mathrm{C}\left(\mathrm{C}_{6} \mathrm{H}_{5}\right) \mathrm{CH}_{2} \mathrm{C}\left(\mathrm{CH}_{3}\right)=\mathrm{N}\right\}\right](\mathrm{acac})_{2}} \\
& {[\mathrm{C}] \rightarrow\left[\mathrm { MoO } _ { 2 } \left\{\left(\mathrm{CH}_{2} \mathrm{CH}_{2} \mathrm{~N}=\mathrm{CC}_{4} \mathrm{H}_{3} \mathrm{~S}-\mathrm{CC}_{4} \mathrm{H}_{3} \mathrm{~S}=\mathrm{NCH}_{2} \mathrm{CH}_{2}\right) \mathrm{N}=\mathrm{C}\left(\mathrm{C}_{4} \mathrm{H}_{3} \mathrm{~S}\right) \mathrm{CH}_{2} \mathrm{C}_{\left.\left.\left(\mathrm{CF}_{3}\right)=\mathrm{N}\right\}\right](\mathrm{acac})_{2}}\right.\right.} \\
& {[\text { D }] \rightarrow\left[\mathrm{MoO}_{2}\left\{\left(\mathrm{CH}_{2} \mathrm{CH}_{2} \mathrm{~N}=\mathrm{CC}_{4} \mathrm{H}_{3} \mathrm{~S}-\mathrm{CC}_{4} \mathrm{H}_{3} \mathrm{~S}=\mathrm{NCH}_{2} \mathrm{CH}_{2}\right) \mathrm{N}=\mathrm{C}\left(\mathrm{C}_{6} \mathrm{H}_{5}\right) \mathrm{CH}_{2} \mathrm{C}\left(\mathrm{C}_{6} \mathrm{H}_{5}\right)=\mathrm{N}\right\}\right](\mathrm{acac})_{2}}
\end{aligned}
$$

\section{Results and Discussion}

One parent complex and their four macrocyclic complexes with Schiff base have been prepared. Using an in-situ method, refluxing the reaction mixture of di-2-thienylethanedione, 1,2-diaminoethane, and molybdenyl acetylacetonate in 1:2:1 molar ratio in aqueous ethanol. This resulted in parent complexes according to schemes 1 and 2. Further cyclization of this parent complexes was done by the reaction of parent complex with 1,3-diketones according to scheme 3.

\subsection{Infrared spectra.}

The IR spectra of complexes are given in table 2. The shifting of $v_{\mathrm{C}=\mathrm{N}}$ to lower frequencies proved the bonding of $\mathrm{N}$-atoms of azomethine groups to the Mo-atom in all macrocyclic complexes [32-36]. $>\mathrm{C}=\mathrm{N}$ absorption proved by the IR bands near $1624-1618$ $\mathrm{cm}^{-1}$. Generally, this type of band normally appears at $1645 \mathrm{~cm}^{-1}$ in ligands [32-35]. IR band present around $303 \mathrm{~cm}^{-1}$ may represent vMo-N mode, which is absent in isolated ligands [37]. The coordination of two keto groups of di-2-thienylethanedione through carbonyl oxygen with $\mathrm{N}$-atom of 1,2-diaminoethane has been proved by the presence of $>\mathrm{C}=\mathrm{N}$ band and the missing of the $>\mathrm{C}=\mathrm{O}$ band around $1710 \mathrm{~cm}^{-1}[38,39]$. Asymmetric and symmetric, the $\mathrm{N}-\mathrm{H}$ stretching vibrations of the coordinated terminal $-\mathrm{NH}_{2}$, were observed at 3352 and $3178 \mathrm{~cm}^{-1}$ [38]. , The formation of the cis-dioxo group is due to the maximum utilization of d-orbital for bonding. Infrared active vibrations viz. the symmetric $\mathrm{Mo}=\mathrm{O}$ stretch at $936-942 \mathrm{~cm}^{-1}$ and asymmetric $\mathrm{Mo}=\mathrm{O}$ stretch at $904-910 \mathrm{~cm}^{-1}$ of complexes of the $c i s-\left[\mathrm{MoO}_{2}\right]^{2+}$ core has $\mathrm{C}_{2} \mathrm{~V}$ symmetry [40]. These bands are assigned to $v_{\mathrm{sym}}(\mathrm{O}=\mathrm{Mo}=\mathrm{O})$ and $v_{\text {asym }}(\mathrm{O}=\mathrm{Mo}=\mathrm{O})$ vibrations respectively [41-44]. In 
general, the vibrational frequencies of $v_{\text {asym }}(\mathrm{O}=\mathrm{Mo}=\mathrm{O})$ vibrations are lower than the ones $v_{\mathrm{sym}}(\mathrm{O}=\mathrm{Mo}=\mathrm{O})$ vibrations $[45,46]$.

The existence of (acac)2 group present at outside coordination circle is demonstrated by the bands appearing around $1513-1517 \mathrm{~cm}^{-1}$ and $1560-1564 \mathrm{~cm}^{-1}$ are relegated to $v_{\mathrm{C}=\mathrm{C}}$ and $v_{\mathrm{C}=\mathrm{O}}$ vibrations [47]. Infrared frequencies of the complexes of type - B show the same pattern of spectral frequencies. The N-H stretching vibrations ( $v_{\operatorname{asym}(\mathrm{N}-\mathrm{H})}$ and $\left.v_{\mathrm{sym}(\mathrm{N}-\mathrm{H})}\right)$ of the terminal $-\mathrm{NH}_{2}$ groups disappear. This is because of the bonding of these $-\mathrm{NH}_{2}$ groups with $>\mathrm{C}=\mathrm{O}$ group of 1,3-diketones in the cyclization processes [47-48].

Table 2. IR spectral bands $\left(v / \mathrm{cm}^{-1}\right)$ of synthesized complexes.

\begin{tabular}{|c|c|c|c|c|c|c|c|c|}
\hline Complex & $\bigcup_{2}^{Z}$ & 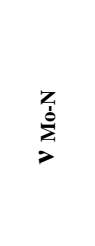 & 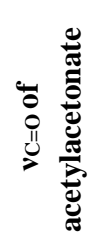 & 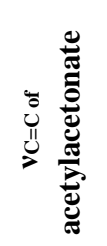 & 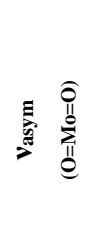 & 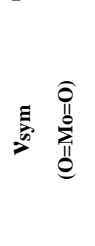 & 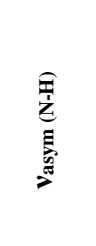 & 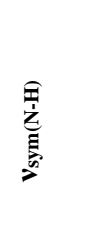 \\
\hline $\begin{array}{l}\text { Macrocyclic } \\
\text { complex [A] }\end{array}$ & $1624 \mathrm{~m}$ & $303 \mathrm{~s}$ & $1560 \mathrm{~s}$ & $1515 \mathrm{~m}$ & $910 \mathrm{~s}$ & $938 \mathrm{~s}$ & & \\
\hline $\begin{array}{l}\text { Macrocyclic } \\
\text { complex [B] }\end{array}$ & $1618 \mathrm{~s}$ & $301 \mathrm{~m}$ & $1564 \mathrm{~m}$ & $1517 \mathrm{~s}$ & $908 \mathrm{~s}$ & $942 \mathrm{~s}$ & & \\
\hline $\begin{array}{l}\text { Macrocyclic } \\
\text { complex [C] }\end{array}$ & $1622 \mathrm{~s}$ & $302 \mathrm{~s}$ & $1560 \mathrm{~s}$ & $1513 \mathrm{~m}$ & $906 \mathrm{~m}$ & $936 \mathrm{~m}$ & & \\
\hline $\begin{array}{l}\text { Macrocyclic } \\
\text { complex [D] }\end{array}$ & $1620 \mathrm{~m}$ & $303 m$ & $1562 \mathrm{~m}$ & $1517 \mathrm{~m}$ & $904 m$ & $942 \mathrm{~s}$ & & \\
\hline Parent complex & $1620 \mathrm{~s}$ & $304 \mathrm{~m}$ & $1564 \mathrm{~s}$ & $1513 \mathrm{~m}$ & $904 \mathrm{~s}$ & $940 \mathrm{~m}$ & $3352 \mathrm{~s}$ & $3178 \mathrm{~m}$ \\
\hline
\end{tabular}

\subsection{UV - Visible spectra.}

The UV spectra of the $\mathrm{MoO}_{2}(\mathrm{VI})$ complexes had been recorded in a solution of DMF of $10^{-3} \mathrm{~mol} \mathrm{~L}^{-1}$ concentration. These signals are interpreted in step with the energy level scheme [47-50]. The UV spectra are similar to those $\mathrm{MoO}_{2}(\mathrm{VI})$ complexes having hetero donor atoms like $\mathrm{N}$-atom. The electronic spectra of these $\mathrm{MoO}_{2}(\mathrm{VI})$ complexes are via a means of strong absorption bands withinside the UV region at $\approx 295 \mathrm{~nm}$, and $\approx 360 \mathrm{~nm}$ appears to be because of LMCT (ligand-to-metal charge - transfer) and intraligand $n \rightarrow \pi^{*} / \pi \rightarrow \pi^{*}$ transitions. The bathochromic shift approximately $20 \mathrm{~nm}$ showed that linkage of the azomethine nitrogen to the molybdenum.

Since $\mathrm{Mo}(\mathrm{VI})$ has $\mathrm{d}^{0}$ configuration, some complexes showed intense medium bands in the area at $\approx 343 \mathrm{~nm}$ and $\approx 394 \mathrm{~nm}$. These bands may be due to LMCT transition between the lowest unoccupied (LUMO) d-orbital of Mo-metal and highest occupied molecular orbital (HOMO) ligands [51-53]. Energy level scheme (Ballhausen-Gray scheme) applied for parent and macrocyclic complexes. The UV spectra show a distorted octahedral configuration for macrocyclic complexes [54].

\subsection{Magnetic and molar conductance measurements.}

Practically, the Mo(VI) complexes are diamagnetic. Because it has a $\mathrm{d}^{0}$ configuration, and no d-d transitions are possible. 1:1 type electrolytes suggested by the molar conductivity $\left(\Lambda_{\mathrm{M}}\right)$ for all formed complexes in DMF at $c a \cdot 10^{-3} \mathrm{M}$. $\Lambda_{\mathrm{M}}$ values of synthesized complexes lie between $95-105 \Omega^{-1} \mathrm{~cm}^{2} \mathrm{~mol}^{-1}$.

All the above data proved the uncertain structures of the complexes of the type A and macrocyclic complexes of type B as shown in schemes 2 and 3. 


\section{Conclusions}

All $\mathrm{MoO}_{2}(\mathrm{VI})$ complexes are ready and structurally characterized. Used spectroscopic spectra have confirmed the formation of complexes to confirm geometry around the $\mathrm{MoO}_{2}(\mathrm{VI})$ center. The distorted octahedral geometry found around Mo in synthesized $\mathrm{MoO}_{2}(\mathrm{VI})$ complexes. Formed Schiff bases have tetradentate ligands properties. It is bonding to the metal ion through the azomethine $\mathrm{N}$-atoms. Analytical data demonstrated the existence of 1:1 of metal ion and ligand molecule. X-ray crystal data of the synthesized complexes, which could ensure the tentative structures, could not be attainable as a result of appropriate crystals, were not isolated.

\section{Funding}

This research was not funded by any agency.

\section{Acknowledgments}

The author is thankful to the Director, NERIST, Nirjuli, Itanagar, Arunachal Pradesh, India, for imparting laboratory facilities and $\mathrm{CRF}$ for microanalysis of $\mathrm{C}, \mathrm{H}$, and $\mathrm{N}$.

\section{Conflicts of Interest}

The authors declare no conflict of interest.

\section{References}

1. Sergienko, V.S.; Abramenko, V.L.; Gorbunova, Y.E. Dioxomolybdenum (VI) Complexes with R1Substituted Salicylidene Allylimines (Hl n): Synthesis and Structure. Crystal Structure of [MoO 2 (L 1) 2](R $1=\mathrm{H})$. Russian Journal of Inorganic Chemistry 2018, $63, \quad 28$ 33,https://doi.org/10.1134/S003602361801014X.

2. Wang, L.; Han, Y.J.; Li, Q.B.; Xue, L.W. Synthesis, crystal structures, and catalytic property of dioxomolybdenum (VI) complexes with hydrazone ligands derived from 3, 5-di-tert-butylsalicylaldehyde. Russian Journal of Coordination Chemistry 2017, 43, 389-395, https://doi.org/10.1134/S1070328417060094.

3. Asgharpour, Z.; Farzaneh, F.; Abbasi, A.; Ghiasi, M. Synthesis, crystal structure and DFT studies of a new dioxomolybdenum(VI) Schiff base complex as an olefin epoxidation catalyst. Polyhedron 2015, 101, 282289,https://doi.org/10.1016/j.poly.2015.09.030.

4. Nag, P.; Sharma, D. Synthesis, characterization and anticandidal activity of dioxomolybdenum (VI) complexes of the type [MoO2 $\{\mathrm{ON}=\mathrm{C}(\mathrm{CH} 3) \mathrm{Ar}\} 2]$ and $\left[\mathrm{MoO} 2\left\{\mathrm{OC}(\mathrm{R}) \mathrm{CHC}\left(\mathrm{R}^{\prime}\right)=\mathrm{NC} 6 \mathrm{H} 5\right\} 2\right]$. Heliyon 2019, 5, e01729,https://doi.org/10.1016/j.heliyon.2019.e01729.

5. Maurya, R.C.; Chourasia, J.; Martin, M.H.; Roy, S.; Sharma, A.K.; Vishwakarma, P. Dioxomolybdenum(VI) chelates of bioinorganic, catalytic, and medicinal relevance: Studies on some cis-dioxomolybdenum(VI) complexes involving O, N-donor 4-oximino-2-pyrazoline-5-one derivatives. Arabian Journal of Chemistry 2015, 8, 293-306,https://doi.org/10.1016/j.arabjc.2011.01.010.

6. Mendel, R.R. Molybdenum: biological activity and metabolism. Dalton Transactions 2005, 34043409,https://doi.org/10.1039/B505527J.

7. Rayati, S.; Rafiee, N.; Wojtczak, A. cis-Dioxo-molybdenum(VI) Schiff base complexes: Synthesis, crystal structure and catalytic performance for homogeneous oxidation of olefins. Inorg. Chim. Acta 2012, 386, $27-$ 35,https://doi.org/10.1016/j.ica.2012.02.005.

8. Karman, M.; Wera, M.; Romanowski, G. Chiral cis-dioxidomolybdenum(VI) complexes with Schiff bases possessing two alkoxide groups: Synthesis, structure, spectroscopic studies and their catalytic activity in sulfoxidation and epoxidation. Polyhedron 2020, 187, 114653,https://doi.org/10.1016/j.poly.2020.114653.

9. Mahmoudi, H.; Bagherzadeh, M.; Ataie, S.; Kia, R.; Heydar Moravej, S.; Zare, M.; Raithby, P.R.; Ferlin, F.; Vaccaro, L. Synthesis and X-ray crystal structure of a Molybdenum(VI) Schiff base complex: Design of a 
new catalytic system for sustainable olefin epoxidation. Inorg. Chim. Acta 2020, 511, 119775,https://doi.org/10.1016/j.ica.2020.119775.

10. Bagherzadeh, M.; Amini, M.; Parastar, H.; Jalali-Heravi, M.; Ellern, A.; Woo, L.K. Synthesis, X-ray structure and oxidation catalysis of a oxido-peroxido molybdenum(VI) complex with a tridentate Schiff base ligand. Inorg. Chem. Commun. 2012, 20, 86-89,https://doi.org/10.1016/j.inoche.2012.02.023.

11. Rao, D.P. A review on versatile applications of novel Schiff bases and their metal complexes. Letters in Applied NanoBioScience 2019, 8(4), 675-681. https://doi.org/10.33263/LIANBS84.675681.

12. Mirzaee, M.; Bahramian, B.; Amoli, A. Schiff base-functionalized boehmite nanoparticle-supported molybdenum and vanadium complexes: efficient catalysts for the epoxidation of alkenes. Appl. Organomet. Chem. 2015, 29, 593-600,https://doi.org/10.1002/aoc.3335.

13. Abdalghani, I.; Biancalana, L.; Aschi, M.; Pampaloni, G.; Marchetti, F.; Crucianelli, M. Dioxomolybdenum(VI) compounds with $\alpha$-amino acid donor ligands as catalytic precursors for the selective oxyfunctionalization of olefins. Molecular Catalysis 2018, 446, 3948,https://doi.org/10.1016/j.mcat.2017.12.018.

14. Zhang, W.G.; Liang, J.H. Synthesis, characterization, and crystal structures of dioxomolybdenum (VI) complexes with $\mathrm{O}, \mathrm{N}, \mathrm{N}$ type tridentate hydrazone ligands as catalyst for oxidation of olefins. Russian Journal of Coordination Chemistry 2017, 43, 411-419,https://doi.org/10.1134/S1070328417060100.

15. Gautam, R.K.; Singh, C.P.; Prasad S.P.; Saxena, R.; Rao, D.P. Synthesis and antibacterial activity of novel molybdenum complexes with macrocyclic Schiff base derived from furanylethanedione. Asian Journal of Chemistry2019, 31, 2607-2612,https://doi.org/10.14233/ajchem.2019.22242.

16. Hossain, M.K.; Haukka, M.; Sillanpää, R.; Hrovat, D.A.; Richmond, M.G.; Nordlander, E.; Lehtonen, A. Syntheses and catalytic oxotransfer activities of oxo molybdenum (VI) complexes of a new aminoalcohol phenolate ligand. Dalton Transactions 2017, 46, 7051-7060,https://doi.org/10.1039/C7DT00846E.

17. Ghosh, S.; Kurapati, S.K.; Pal, S. Complexes of cis-dioxomolybdenum(VI) with a chiral tetradentate tripodal-like ligand system: Syntheses, structures and catalytic activities. Polyhedron 2017, 125, 2633,https://doi.org/10.1016/j.poly.2016.08.025.

18. Holm, R.H. Metal-centered oxygen atom transfer reactions. Chem. Rev. 1987, 87, 14011449,https://doi.org/10.1021/cr00082a005.

19. Eğlence, S.; Şahin, M.; Özyürek, M.; Apak, R.; Ülküseven, B. Dioxomolybdenum(VI) complexes of Smethyl-5-bromosalicylidene-N-alkyl substituted thiosemicarbazones: Synthesis, catalase inhibition and antioxidant activities. Inorg. Chim. Acta 2018, 469, 495-502,https://doi.org/10.1016/j.ica.2017.10.007.

20. Nag, P.; Bohra, R.; Mehrotra, R.C. Dioxomolybdenum (VI) complexes as catalytic neutral esterification agents. Journal of Chemical Research 2002, 2002, 86-88,https://doi.org/10.3184/030823402103171249.

21. Majumder, A.; Rosair, G.M.; Mallick, A.; Chattopadhyay, N.; Mitra, S. Synthesis, structures and fluorescence of nickel, zinc and cadmium complexes with the N,N,O-tridentate Schiff base N-2pyridylmethylidene-2-hydroxy-phenylamine. Polyhedron $\quad 2006, \quad 25, \quad 1753-$ 1762,https://doi.org/10.1016/j.poly.2005.11.029.

22. Sergienko, V.S.; Abramenko, V.L.; Surazhskaya, M.D. Intracomplex Dioxomolybdenum (VI) Compounds with Alcoholimines of Aromatic o-Hydroxyaldehydes. Crystal Structure of 2-Hydroxynaphthylidene Monoethanolimine (H 2 L) and Solvated Complex [MoO 2 (L). C 5 H 5 N]. Russian Journal of Inorganic Chemistry 2020, 65, 495-501,https://doi.org/10.1134/S0036023620040166.

23. Gupta, K.C.; Sutar, A.K. Catalytic activities of Schiff base transition metal complexes. Coord. Chem. Rev. 2008, 252, 1420-1450,https://doi.org/10.1016/j.ccr.2007.09.005.

24. Kim, W.-S.; Choi, Y.-K. Electrocatalytic effects of thionyl chloride reduction by polymeric Schiff base transition metal(II) complexes. Applied Catalysis A: General 2003, 252, 163172,https://doi.org/10.1016/S0926-860X(03)00414-9.

25. Hayashi, T. Catalytic asymmetric reactions via $\pi$-allylpalladium complexes coordinated with chiral monophosphine ligands. J. Organomet. Chem. 1999, 576, 195-202,https://doi.org/10.1016/S0022328X(98)01058-4.

26. Helmchen, G. Enantioselective palladium-catalyzed allylic substitutions with asymmetric chiral ligands. $J$. Organomet. Chem. 1999, 576, 203-214,https://doi.org/10.1016/S0022-328X(98)01059-6.

27. Brunner, H.; Deml, I.; Dirnberger, W.; Nuber, B.; Reißer, W. Enantioselective Palladium-Catalysed Allylation of 1, 5-Dimethylbarbituric Acid. Eur. J. Inorg. Chem. 1998, 1998, 4354,https://doi.org/10.1002/(SICI)1099-0682(199801)1998:1<43::AID-EJIC43>3.0.CO;2-S. 
28. Mehta, B.H.; Nagarkoti, B.S. Synthesis and characterization of some transition metal complexes of 2naphthoin oxime. Asian J. Chem. 2002, 14, 103.

29. Hall, I.H.; Lee, C.C.; Ibrahim, G.; Khan, M.A.; Bouet, G.M. Cytotoxicity of metallic complexes of furan oximes in murine and human tissue cultured cell lines. Appl. Organomet. Chem. 1997, 11, 565-575, https://doi.org/10.1002/(SICI)1099-0739(199707)11:7<565::AID-AOC608>3.0.CO;2-I.

30. Vogel, A.I. A Text book of quantitative Inorganic analysis, 4th ed.; Longmans Green Co. Ltd., London, 1978.

31. Vogel, A.I. A Text book of practical organic chemistry, 4th ed.; Longmans Green Co. Ltd., London, 1978.

32. Offiong, O.E.; Martelli, S. Synthesis and biological activity of novel metal complexes of 2-acetylpyridine thiosemicarbazones. Farmaco (Societa Chimica Italiana: 1989) 1995, 50, 625-632.

33. Rana, V.B.; Singh, P.; Singh, D.P.; Teotia, M.P. Trivalent chromium, manganese, iron and cobalt chelates of a tetradentate N 6 macrocyclie ligand. Transition Met. Chem. 1982, 7, 174177,https://doi.org/10.1007/BF01035836.

34. Chandra, S.; Sharma, K.K. Synthesis and characterization of copper (II) complexes of a macrocyclic ligand. Transition Met. Chem. 1983, 8, 1-3,https://doi.org/10.1007/BF00618784.

35. Malik, W.U.; Bembi, R.; Singh, R.; Taneja, S.P.; Raj, D. Preparation and characterisation of some new 12and 14-membered dibenzotetraaza macrocyclic complexes of iron (III). Inorg. Chim. Acta 1983, 68, 223228,https://doi.org/10.1016/S0020-1693(00)88965-3.

36. Głowiak, T.; Jerzykiewicz, L.; Sobczak, J.M.; Ziółkowski, J.J. New insights into the chemistry of oxomolybdenum (VI) complexes with N-salicylidene-2-aminoethanol. Inorg. Chim. Acta 2003, 356, 387392,https://doi.org/10.1016/S0020-1693(03)00301-3.

37. Ferraro, J.R.Low Frequency Vibrations of Inorganic and Coordination Compounds. Plenum Press, New York, 1971.

38. Dyer, J.R. Applications of absorption spectroscopy of organic compounds. 1965.

39. Singh, S.; Rao, D.P.; Yadava, A.K.; Yadav, H.S. Synthesis and characterization of oxovanadium (IV) Complexes with tetradentate schiff-base ligands having thenil as precursor molecule. Current Research in Chemistry 2011, 3, 106-113,https://doi.org/10.3923/crc.2011.106.113.

40. Willis, L.J.; Loehr, T.M.; Miller, K.F.; Bruce, A.E.; Stiefel, E.I. Raman and infrared spectroscopic studies of dioxomolybdenum(VI) complexes with cysteamine chelates. Inorg. Chem. 1986, 25, 42894293,https://doi.org/10.1021/ic00243a045.

41. Ceylan, B.I.; Kurt, Y.D.; Ülküseven, B. Synthesis and characterization of new dioxomolybdenum (VI) complexes derived from benzophenone-thiosemicarbazone (H2L). Crystal structure of [MoO2L (PrOH)]. $J$. Coord. Chem. 2009, 62, 757-766,https://doi.org/10.1080/00958970802339669.

42. Maurya, R.C.; Verma, R.; Singh, T. Synthesis, magnetic, and spectral studies of some mono-and binuclear dioxomolybdenum (vi) complexes with chelating hydrazones derived from acid hydrazides and furfural or thiophene-2-aldehyde. Synth. React. Inorg. Met.-Org. Chem. 2003, 33, 309325,https://doi.org/10.1081/SIM-120017789.

43. Wang, X.; Zhang, X.M.; Liu, H.X. Synthesis, characterization and crystal structure of a cis-dioxo molybdenum (VI) complex of the schiff base Girard reagent T (salt). J. Coord. Chem. 1994, 33, 223228,https://doi.org/10.1080/00958979408024280.

44. Rao, D.P.; Yadav, H.S.; Yadava, A.K.; Singh, S.; Yadav, U.S. Syntheses and spectroscopic studies on macrocyclic complexes of dioxomolybdenum (VI) with furil as precursor. Journal of Chemistry 2012, 9, 497-503,https://doi.org/10.1155/2012/205123.

45. Cotton, A.F.; Wilkinson, G.; Bochmann, M.; Murillo, C.A. Advanced inorganic chemistry. 1999,18, 944947.

46. Nakamoto, K. IR and Raman spectra of Inorganic and coordination Compound, part A and B. John Wiley and Sons, New York, 1998.

47. Gehrke, H.; Veal, J. Acetylacetonate complexes of molybdenum(V) and molybdenum(VI). I. Inorg. Chim. Acta 1969, 3, 623-627,https://doi.org/10.1016/S0020-1693(00)92563-5.

48. Yadav, H.S. Synthesis of spectroscopic studies of oxovanadium(IV) complexes with 16- and 18-membered macrocyclic ligands. Polyhedron 1993, 12, 313-317,https://doi.org/10.1016/S0277-5387(00)81729-5.

49. Rao, D.P.; Yadav, H.S.; Yadava, A.K.; Singh, S.; Yadav, U.S. In-situ preparation of macrocyclic complexes of dioxomolybdenum (VI) involving a heterocyclic precursor. J. Coord. Chem. 2011, 64, 293299,https://doi.org/10.1080/00958972.2010.544037. 
50. Sakata, K.; Kuroda, M.; Yanagida, S.; Hashimoto, M. Preparation and spectroscopic properties of oxovanadium(IV) and dioxomolybdenum(VI) complexes with tetraaza[14]annulenes containing pyridine rings. Inorg. Chim. Acta 1989, 156, 107-112,https://doi.org/10.1016/S0020-1693(00)90375-X.

51. Garg, R.; Saini, M.K.; Fahmi, N.; Singh, R.V. Spectroscopic and biochemical studies of some manganese (II), Oxovanadium (V) and Dioxomolybdenum (VI) complexes S/O and N donor agents synthesized under microwave conditions. Transition Met. Chem. 2006, 31, 362-367, https:/doi.org/10.1007/s11243-005-00011.

52. Gautam, R.K.; Singh, C.P.; Saxena, R.; Rao, D.P. SYNTHESIS AND STUDIES OF SOME cis-MoO2 (VI) COMPLEXES WITH NITROGEN DONOR MACROCYCLIC LIGANDS. European Chemical Bulletin 2019, 8, 387-393,http://dx.doi.org/10.17628/ecb.2019.8.387-393.

53. Kahrović, E.; Molčanov, K.; Tušek-Božić, L.; Kojić-Prodić, B. New complexes of Mo(V) with Schiff bases: Crystal structure of butylammonium di- $\mu$-oxo- $\mu$-acetato-bis[(N-butylsalicylideniminatoN,O)oxomolybdenum(V)] benzene, acetic acid solvate. Polyhedron 2006, 25, 24592464,https://doi.org/10.1016/j.poly.2006.02.008.

54. Ballhausen, C.J.; Gray, H.B. The Electronic Structure of the Vanadyl Ion. Inorg. Chem. 1962, 1, 111122,https://doi.org/10.1021/ic50001a022. 